\title{
"Easternization" of Post-Western International Order: Appertaining Confucianism into Bandung Conference Legacy
}

\author{
Dedi Dinarto \\ Universitas Gadjah Mada
}

\begin{abstract}
This paper seeks to develop non-Western theory in IR, particularly appertaining Confucianism into the formation of new global order. Arguably, the role of China in international order has generated debates for IR theorists, which ended in two main conclusions, China as a new hegemonic power or responsible power. It is presumably caused by the diffusion of power in post-Cold War global order, in which China seeks for revival after the 'century of humiliation' caused by Western presence in early $20^{\text {th }}$ century. Moreover, the model of China's leadership under Xi Jinping in which global order is assumed to be related with the revival of Confucianism. Stressing on mutual cooperation, China seeks to shift the international paradigm disorder dominated by the western idea of materialism. Distinctively, this paper will illustrate the notion of Chinese role in the global order by taking its connection with the formation of Bandung Conference. As one of the global leading power, China could play greater role in international sphere, among other by uniting members of developing countries in the Bandung Conference to revivethe alternative way of global order management. Furthermore, the promotion of Chinese Dream as the manifestation of the essence of confucianism under Xi Jinping could become the starting point toward "easternization" of global order under Bandung Conference legacy.
\end{abstract}

Keyword: confucianism, China, Xi Jinping, Bandung Conference legacy, easternization.

\begin{abstract}
Abstrak
Tulisan ini berusaha mengembangkan teori non-Barat dalam ilmu Hubungan Internasional, terutama menghubungkan Konfusianisme ke dalam formasi tatanan global baru. Bisa dibilang, peran Tiongkok dalam tatanan internasional telah memunculkan debat bagi teoretikus-teoretikus HI, yang berujung pada dua kesimpulan utama, Tiongkok sebagai sebuah kekuatan hegemoni baru atau kekuatan yang bertanggung jawab. Hal ini agaknya disebabkan oleh difusi kekuatan di tatanan dunia pasca Perang Dingin, dimana Tiongkok berusaha untuk bangkit setelah 'abad penghinaan' yang disebabkan oleh keberadaan Barat di awal abad ke 20. Terlebih lagi, model kepemimpinan Tiongkok di bawah Xi Jinping di tatanan global menuntut pada kebangkitan Konfusianisme. Menekankan pada saling kerjasama, Tiongkok ingin mengubah paradigma kekacauan internasional yang didominasi oleh materialisme ide Barat. Secara berbeda, tulisan ini akan mengilustrasikan gagasan peran Tiongkok di tatanan global dengan menghubungkannya pada formasi Konferensi Bandung. Sebagai salah satu pemimpin kekuatan global, Tiongkok bisa saling memberikan pengaruh dengan lingkup internasional, sekaligus mempersatukan negara-negara berkembang di Konferensi Bandung untuk membangkitkan kembali jalur alternatif manajemen tatanan global. Lebih lanjut, promosi Mimpi Tiongkok oleh Xi Jinping yang termanifestasi dari esensi Konfusianisme dapat menjadi langkah awal menuju "easternization" tatanan global di bawah warisan Konferensi Bandung.
\end{abstract}

Kata kunci: konfusianisme, Tiongkok, Xi Jinping, warisan Konferensi Bandung, easternization 


\section{Introduction}

In building the plausible connection between Confucianism and Bandung Conference legacy, it is important to look at the essence of nonWestern International Relations theory (simplified as IRT). Known as non-Western IRT, Confucianism plays prominent role in shaping or simply becoming the antidote to the faults of Western culture (Hwan, 2006, p. 3435). Different from hard theory, Confucianism works as the 'aesthetic' component inside the Western product, such as sovereignty and regime. This notion demonstrates that Confucianism works essentially in how to develop the ethic and ideas of the subject, rather than the systemic aspects. Amitav Acharya and Barry Buzan have identified that there are several non-Western contributions that fit broadly within the understanding of IRT even if they are more likely to fit into the conception of soft rather than hard theory due to their focus on ideas and beliefs (Acharya and Buzan, 2010, p. 10). Moreover, Rainey explained that a superior Confucianism was to act as the base of a modern society, while Western technology was only for practical use. At this point, we could classify Confucianism as one of non-Western IRT to understand international relations within the softer framework.

Confucianism had become a prominent perspective in viewing China since the ancient until contemporary era. As early as $551 \mathrm{BCE}$, a great sage of education was born in the state of $\mathrm{Lu}$, which contemporarily known as Shandong, one of People's Republic of China's province. At that time, the declining power of Zhou Dynasty was significant when they fell off into non-Chinese enemies. This resulted in the assassination of the King. This situation is perfect for the local lords to arise and stabilize the political instability after the Zhou era. This condition mandated Confucius to develop his manifestation of harmonious and peaceful approach for soothing violence, greed, and hunger over power. Passing through many injustice, obscurity, and uncertainty of political conflicts, Confucius had to promote his approach toward the conflict resettlement. At the end, though he had failed to prevent the death caused by war, Confucius finally come back to the state of $\mathrm{Lu}$ and produced some writings of his teachings which contemporarily known as the Analects. Since his death in 479 $\mathrm{BCE}$, his prominent way of thinking has been used to develop Chinese society, in term of political, economic, social, and cultural systems for approximately two millennia. Nowadays, various interpretations toward Confucius' thought have been set out by Mencius, Xun Zi, New Text scholars, and NeoConfucian thinkers. On the other hand, the presence of Chinese Communist Party (CCP) has replaced Confucianism as political philosophy even if being revived under $\mathrm{Xi}$ Jinping's leadership.

Afterwards, discussing about Confucianism will lead us to the problematic question: which Confucianism that is plausible to help understanding the correlation between China's role-which are generally understood as hierarchic global order-with the formation of Bandung Conference legacy-which was built for coexistence, equal, and peaceful cooperation among members?

Lee Seung-hwan had said, "Confucianism is a discourse with a thousand faces" (Hwan, 2006, p. ix-xi). This justification leads us to understand that Confucianism has been broadly interpreted. For instance, since the first era of Confucius, it has been interpreted several times by Mencius, Xun Zi, New Text scholars, and Neo-Confucian thinkers. This idea has also been interpreted by "Boston Confucians", a group of New Confucians centered on the city of Boston consisting of Tu Wei-ming of Harvard, and Robert Neville and John Berthrong of Boston University (Rainey, 2010, p. 193). However, despite using the rest of those interpretations, this paper will identify Xi's Confucianism which has given significant contribution to China's foreign policy. The main analysis of this paper will be divided into three sections: first, the understanding of Confucianism toward international order; second, the identification of Xi Jinping and his Confucianism to the global order; and lastly, debating the possibility of "easternization" over post-Western international order.

\section{Confucianism and the Interpretation of International Order}

Generally, there are three levels of analysis that can work under the manifestation of 
Confucianism. ${ }^{1}$ They are to be a good person (individual), a good society (state), and beyond society (international). At the international level, Confucianism is basically understood as "hierarchic model of world" on state-society relations. In spite of seeing Confucianism superficially, we could examine the relationship of Confucianism and the international order as far as from Confucius, Mencius, until $\mathrm{Zhu} \mathrm{Xi}$ with its NeoConfucianism, signifying the fact that Confucianism has developed with distinctive characteristics to understand the world.

Firstly, the classical way to understand Confucianism heavily refers to Analects as the primary source of Confucius's writings. Philosophically, understanding individual as a single actor and its relation with others, we could make an analogy of a gentleman who is being "Good". In term of "Goodness", Confucius prescribed:

"Someone could be considered 'Good'owho is able to, everywhere in the world, put five virtues into practice."May I ask what these virtues are?" Reverence, magnanimity, trustworthiness, diligence, and kindness. If you are reverent, you will avoid disgrace; if you are magnanimous, you will win the populace; if you are trustworthy, others will put their trust in you; if you are diligent, you will achieve results; and if you are kind, you will have the wherewithal to employ the people" (Confucius, 2003, p. 202).

Merely, the "Goodness" was simplified as, "Fan Chi asked about Goodness. The Master replied, "Care for others" (Confucius, 2003, p. 126). After being "Good", it is necessary to look at how a good person should maintain its relations with other person-instead good or bad person-as it depicts the relationship between China and other states, in which Confucius prescribed, "Virtue is never solitary; it always has neighbors" (Confucius, 2003, p. 37) and, "A gentleman helps others to realize their good qualities, rather than their bad. A petty person does the opposite" (Confucius, 2003, p. 133). Clearly stated, as a "responsible gentleman", a person should behave in line with the virtue and assist other people to be cleared in implementing the virtue. Hence, a state which manifested the "virtue" as political philosophy is obligated to promote such virtue to other states. Put it simply, the "virtue socialization" ought to promote goodness all over the world. Therefore, this relationship could be seen to have harmony and coexistence as its main feature instead of hierarchy as perceived by many. This relationship, however, still acknowledged individuals and states as the ideal actor-regardless power and political intention.

Secondly, after Confucius, Confucianism was interpreted by the so-called Second Sage Mencius who had put some different dimensions on his thought. His main argument on inter-state relations was described by Jeremy Paltiel to have three prominent elements, namely collective good, inter-subjectivity, and logic of appropriateness (Paltiel, 2010, p. 42-43). Mencius meant collective good through an understanding of self-interest. Even if both terms of collective good and self-interest are contradictory, Mencius offers a plausible understanding of how self-interest could be addressed through public interest by taking into account of others before individual good. In this term, he pursued to reach intersubjectivity, where the self-action could determine the others' behaviors while simultaneously creating social relations under mutual trust.

Moreover, Mencius comes with a striking debate between logic of appro-

${ }^{1}$ As Lee has explained on both of individual and state level within Confucius' thought (see Lee Dian Rainey, Confuciusp. 23-61). 
priateness and logic of consequences. $\mathrm{He}$ believed that by having an inter-subjectivity, a suggestion that extremely unimagined logically could be perceived and believed for common, and hence accepted under the logic of consequences. The construction and discourse on certain idea could also be received logically as normative foundation of social life. Therefore, Mencius argued that collective society could be created by transforming the self-material desire into common interest. Mencius suggested implicitly a collective world which could be achieved through the establishment of sympathy and empathy in inter-state relations. Taking into account the other's interest before self-interest depicts the agent's role in creating and establishing imagined structure for mutual trust relationship between subjects. Modestly, he imagined that the world is a united and living coexistence. Hence, his explanation puts more plausible proto-ideal thought due to its acknowledgement of power and self-desire.

Thirdly, Neo-Confucianism has called for a better way to understand Confucianism in broader scope targeting international sphere as a unit of analysis. The turning point of understanding Confucianism came from Zhu $\mathrm{Xi}$ (1130-1200), the founder of NeoConfucianism in the era of Song Dynasty, who describes the world as Tian Xia. He described the system of world virtue as:

"The extension of knowledge consists in the investigation of things. When things are investigated, knowledge is extended; when knowledge is extended, the will is sincere; when the will is sincere, the mind is rectified; when the mind is rectified, the personal life is cultivated; when the personal life is cultivated, the family will be regulated; when the family is regulated, the state will be in order; and when the state is in order, there is peace throughout the world" (Tian Xia, 2008, p. 43).

In his explanation, the conception of Tian Xia as a peace world should be achieved through the implementation of Great Learning in individual, domestic, and international level in advance. Zhu Xi explained that Great Learning should be accomplished as he stated, "It recommends that the steps for such an achievement should be "investigation of things", "achievement of knowledge", "sincerity of the will", "rectification of the heart", "cultivation of oneself", "regulation of the family", "government of the state", and finally, "making the whole world just and peaceful" (Ming, p. 314). Thus, world peace could only be achieved gradually through individual level up to international level. As the first modern student who took Tian Xia as an explanation for China's international behavior, Liang Qichao (1873-1929) stated his prominent argument on China's peace global order, and wrote that "the Chinese people have never considered national government as the highest form of social organization. Their political thinking has always been in terms of all mankind, with world peace as the final goal, and family and nation as transitional stages in the perfecting of world peace" (Chan, 2008, p. 67). He perceived that the world peace can only be achieved from the process of one's mind manifestation in understanding the necessity of human life's prosperity. This ideal view within Neo-Confucianism is considered in the last stage: China would bring peace and harmony towards the global order.

Those three prominent thinking of Confucianism have shown us the necessity of togetherness rather than selfishness. Most of Confucianism philosophies put idealism as the basic morality to produce virtue. The virtue of Confucianism applied in international level turns to inquire "how the world should be". Imagining the world of utopia such as Immanuel Kant, Hugo Grotius, and Hedley Bull, Confucianism tends to harmonize the inter-state relations. Inside the Analects, Confucius explained the importance of man's principles to measure his external world as followed:

"Zizhang asked about getting by in the world (xing). The Master replied, 'In your speech, be dutiful and trustworthy, and in your conduct be sincere and 
respectful. In this way, you will always get by in the world, even if you find yourself in some barbarian state. If your words are not dutiful and trustworthy, and your conduct is not sincere and respectful, how can you possibly get along, even in your own region? When standing still, visualize these principles standing by your side; when riding in your carriage, see them resting before you on the crossbar. Only then will you get by in the world"” (Confucius, 2003, p. 176).

This explanation shows that the world which was created with asymmetric structure requires a central country (man) which needs to pursue his Great Learning towards itself and the other states. Theoretically, it shows the relationship between agent and structure as interconnected and influences each other. As stated in Wendt's work, "It is through reciprocal interaction that we create and instantiate the relatively enduring social structures in terms of which we define our identities and interests" (Wendt 1992, p. 406). This scheme offered the world of peace and harmonious order in inter-states relationship, inevitably diminishing the self-political intention of agent towards structure.

\section{Xi's Confucianism on International Order and Its Critics}

Confucianism is often identified as Chinese political philosophy due to its prominent role in shaping the traditional and modern life of China. Since early period, Confucianism has contributed in promoting peace during Warring States era. This philosophy, however, was neither developed nor implemented, or let alone, promoted during the Han Dynasty up until Tang Dynasty era. Hence, Confucianism was rapidly interpreted as a reaction of Chinese territorial losses to external invaders. This condition lured out the interpretation toward Confucianism which then resulted in the notion of Neo-Confucianism by $\mathrm{Zhu} \mathrm{Xi}$. Political context, in this sense, has become the basis for the development of Confucianism theory, reflecting exactly what Robert Cox means when saying that "theory is always for someone and for some purpose" (Cox, 1986, $\mathrm{p}$. 207). Following this fact, therefore, it is also important to see how Confucianism is being interpreted according to the political context.

In recent era, for example, the discussion of Confucianism has attracted attention from IR scholars particularly when Xi Jinping, the leader of People's Republic of China, took responsibility to revive Confucianism as a response to China's internal and external instability. He aimed to humanize Chinese Dream by taking into account the context of Confucius, the long Chinese tradition of Confucianism, and the legacy of Confucius for both the domestic public and the international community (Kai, 2014). Domestically, under the framework of Chinese Dream, $\mathrm{Xi}$ is the most inspirational and identity-forming leader after Mao's legacy, with Chinese Dream itself as an imagination to revive nationalism and brilliant cooptation of individual prosperity in support of collective economic and military success (Yang and Vaughn, 2014, p. 179). As he delivered the speech about "peace in the minds of men", Xi imagined the world of peace under Confucius' framework as:
Coordinate and seek harmony with all nations; associating with the benevolent and befriending neighbors is a precious virtue of the state; within the four seas, all men are brothers; a far-off relative is not as helpful as a near neighbor; neighbors wish each other well, just as loved ones do to each other; a warlike state dies inevitably, no matter how big it is (Gardels, 2014).

Through his idea about the world of peace, it is understandably that Xi refers his thought to Confucius' virtue and moral prescription. $\mathrm{He}$ still interpreted it necessarily despite being under certain political context particularly related to the moral void after the decline of communist ideology; social tensions resulting from the widening income gap, blind pursuit of 
materialism, and declining integrity and honesty; and the growing acceptance of Western cultural and democratic values (Xiangwei, 2014). All of these occurred concurrently with the remaining sense of historical experience when China suffered from "century of humiliation" (bainian guochi) ${ }^{2}$ due to Western's presence at East Asia-formerly known as Far East-in the end of $2 \mathrm{O}^{\text {th }}$ century. After Deng Xiaoping's open door policy, the reassertion of the Chinese People by Jiang Zemin, and the peace development by $\mathrm{Hu}$ Jintao, Xi Jinping aims to reassert the "Chinese identity" by implementing Confucianism. As he stated, "Confucianism, along with other philosophies and cultures taking shape and growing within China, are records of spiritual experiences, rational thinking and cultural achievements of the nation while it strived to build its identity" (Xuequan, 2014).

On the other hand, the revival of Confucianism also corresponds to China's internal and external problem, wherein changing China's behavior-to be the influencing power-will affect international constellation. In Mingjiang Li's work, Fareed Zakaria claims that "China has used soft power only in the sense that it has exercised its power softly. It does this consciously to show that it is not a bully" (Mingjiang Li, 2009, p. 2). However, since the international order is shifting and transforming, China's behavior cannot be categorized only by looking at its soft power. As David Shambaugh clearly explained:

China is the world's most important rising power. In two decades, China has moved from the periphery to the center of the international system. Every day and everywhere, China figures prominently in global attention. Wherever one turns, China is in the newsgobbling up resources, soaking up investment,

\footnotetext{
2 For a detailed explanation about the "century of humiliation", see Christian A. Hess, "Keeping the Past Alive: The Use of History in China's Foreign Relations"
}

expanding its overseas footprint, asserting itself in its Asian neighborhood, being the sought after suitor in global governance diplomacy, sailing its navy into new waters, broadening its global media exposure and cultural presence, and managing a mega-economy that is the engine of global growth (Shambaugh, 2013, p. 4).

In this case, there are two important aspects that should be underlined, namely China's approach based on moral and its goal to alleviate the Western domination as the prescription towards post-Western international order. Obviously, in the case of China under $\mathrm{Xi}$, Confucianism as a philosophy is used to reduce the raising concern over the perception of China's hegemony. China has the national interest to be pursued in harmonious and unified way. For Xi, the moral basis is important not only to hide China's political intention but also to pursue mutual interests over self-interests. In the work of Theodore de Bary, et al., they cited the prominent words of Ye Dehui which stated, "The upholding of Confucianism leads to good government while the adoption of foreignism leads to disorder and that in so far as there is morality, 'there must be Confucianism"' (de Bary, Chan, and Tan, 1960, p. 80-81). Even though it is morally accepted, some of the impact of this approach would be hidden within them, which is a code of conduct that emphasizes acceptance of strict hierarchy, respect for social order, and deference to authority ( $\mathrm{Lu}, 2014)$.

It remains to be seen whether China aimed to counter Western idea which has suppressed the development of Third World countries, including China itself. Some scholars asked how the Western maintains its presence in international order even though it has severely caused backwardness of developing countries. Pichamon Yeophantong

Handbook of China's International Relations, ed. Shaun Breslin (New York: Routledge, 2010) 47-54. 
criticized the neoliberal value promoted by the West as discriminating against developing, non-Western powers like China and impeding the development of a truly "global" system of governance-one representative of the cultural heterogeneity and diversity of interests of an evolving world society (Yeophantong, 2013, p. 345). He stressed that the Western value has masqueraded the international order and brought down the other value to be "injustice".

Nevertheless, Daniel Bell viewed that the Confucianism approach implemented by Xi Jinping and the former leaders of China would be the prefix to become a great power within the international order. $\mathrm{He}$ stated, "Internationally, the call for peace and harmony is meant to disarm fears about China's rise" (Bell, 2008, p. 24). He also stated, "In practice, the Confucian ideal of Great Harmony would mean a foreign policy that promotes international peace while allowing for legitimate national self-interest that can sometimes outweigh cosmopolitan ideal" (Lanteigne, 2009, p. 44). Both statements refer to how Daniel perceived greater concept of world promoted by some Chinese scholars like Tian Xia. He argued that this concept could not work as an accurate framework in understanding China when it has reached global dominance. There is an effort to hide the political reason behind the rise of China using peace and harmony. Therefore, Bell argued that foreign actions of China contain political intention, even if it is covered by "peace"-and"harmony"- image of China, beyond its Confucianism.

Moreover, Joanna Liu in her comparative work argued that "following the onset of modernization in either country, Chinese and North Korean leaders have 'critically inherited' or selectively used aspects of Confucianism for their own political purposes, which are usually geared toward ensuring their power and regime stability" (Liu, 2014, p. 68). Similar with Bell's argument, Liu proved that the reinterpretation of Confucianism thinking by Xi Jinping was only used to legitimate his legacy. Xi aimed to resolve the domestic problem as well as the international affairs so he could come as a leading power which, in certain context, reducing the essence of Confucianism. Hence,
IR scholars predict the domination of China in the post Western international order. At this point, China is perceived as the new leading global power that can encounter dominant Western order.

\section{Revealing "Easternization"aof Post- Western International Order: China to- wards Bandung Conference Legacy}

Following the formation of Bandung Conference, China was not yet seen as a prominent actor. The reason why China joined Bandung Conference was because Nehru had a strong interest in having China to attend the conference, as it could be used to diffuse tensions with other Asian states over its rather controversial alliance (Nehru, 1985, p. 85). However, Sir John Kotelawala was cautiously supportive, careful that such conference would give an open forum to communist countries like China, North Korea and the newly forming South Vietnam (Kotelawala, 1956, p. 276). His concern towards those communist countries, including China, was due to ideological unity with Soviet Union, which was competing against the United States within the context of Cold-War order. Ali Sastroamidjojo, who was properly considering the presence of colonialized countries to strengthen the power of non-aligned, denied this issue afterwards. Such negotiation led to a noteworthy reversal by Nehru, who began to view the conference as another chance for expanding India's program of non-alignment (Kimche, 1973, p. 66). As China could be the vital pivot in East Asia region, Nehru dreamed for expanding his influence.

However, Nehru's attitude change was basically caused by the idea of Zhou Enlaiformer Prime Minister of China-who wanted to put an initiative to formulate the Five Principles of Peaceful Coexistence when Zhou did the visit to New Delhi before the conference began (Anwar, 2008, p. 183). It can be seen in Zhou Enlai's speech in the conference stating that:

The peoples of Asia and Africa created brilliant ancient civilizations and made tremensdous contributions to mankind. But, ever since 
modern times, most of the countries of Asia and Africa, in varying degrees have been subjected to the plunder and oppression of colonialism, and have been forced to remain in a stagnant state of poverty and backwardness (Aghazarian, 2012, p. 40-41).

This speech gave significant influence to the formation of Southern World, since he stressed out the importance of "mutual respect for territorial integrity", "non-interference in each other affairs", and "the peaceful coexistence of countries with different social systems" (Aghazarian, 2012, p. 41).

In this regard, China's initiative towards Bandung Conference at that time was obviously based on its political intention. China's attendance was based on such, as it wanted to use the conference to defeat the Western isolation imposed on it (Finnane, 2010, p. 109). It means China was not willing to involve in Cold War illness. According to Ronald Keith, China had been trying to branch out from its diplomatic dependence on the Soviet Union, a task that was extremely difficult given its level of isolation from the rest of the world (Keith, 1989, p. 34). In order to alleviate Soviet Union's political control, what China had been done was prodigiously counterattacked by establishing the Chinese People's Association for Friendship with Foreign Countries, which was responsible for "the establishment of cultural relations with foreign countries" (Keith, 1989, p. 34). Through this historical experience, we cannot give a justification for China over its political control. Under Zhou Enlai, China was known as a prominent actor that can shape the sustainability of Southern countries' cooperation. At this point, we can look over the alleviation of Soviet Union's domination over non-alignment countries as a counter-value promotion as well as integrating the understanding of Southern countries on bipolar international order.

In recent era, it is notably important to look at China's action to manifest their political philosophy value to built mutual coexistence and peaceful cooperation. According to Yan
Xuetong, China's rise will be more effectively achieved by fostering friendly ties with neighboring countries, rather than focusing on improving U.S.-China relations in order to reduce "American resistance" (Thomas 2015). Xi himself has declared that the "Panchsheel" or the Five Principles of Peaceful Coexistence would become the reference for Beijing having diplomatic dealings with every nation (Krishnan 2014). However, there are some empirical cases which show Xi's implementation of "Panchsheel" over its relation with India and Indonesia, two prominent actors of the Bandung Conference legacy. In the first stage, to clarify China's cooperation with India, Foreign Minister Wang Yi visited to New Delhi to emphasized the SinoIndia relation in a new age of gearing up, as stated by Chinese Foreign Ministry Spokesperson, Hua Chunying, that:

Chinese leaders pay attention to growing relations with India, common interests between the two countries far outweigh disputes. ... We are natural partners rather than rivals and the Chinese and Indian dream integrate with each other, so we should build closer development partnership with each other, and We believe that the development of Sino-India relations are not only in the benefits of the two people but will also help peace, stability and development of the region and beyond (Panda, 2014).

It is observed that China has a rhetoric vision toward India, while maintaining partnership and stressed out the importance of coexistence and equal cooperation. On the other hand, as a response to China's diplomatic effort toward India, Indian Foreign Minister Sushma Swaraj claimed that the Sino-India relationship should be emphasizing the newness, in which correlating to the border dispute that must be settled before the next development agenda (Tiezzi, 2015). From these state-to-state claims, the prospect renewing Sino-India relation could be achieved, in accordance to 
Prime Minister Narendra Modi's visit to China in May 2015, which will progressively discuss the settlement of disputed border.

Secondly, the most recent issue is between China and Indonesia. During his visit to China, Indonesia's President Joko Widodo acknowledged the presence of China to foster Indonesia's development and officially invited Xi Jinping to attend the Asia-Africa Summit's $60^{\text {th }}$ Conference in Bandung (Utami, 2015). Undoubtedly, this invitation was based on their commitment in the Joint Statement on Strengthening Comprehensive Strategic Partnership between the People's Republic of China and the Republic of Indonesia, which stated that:

The two sides shared the view that the Bandung Conference was a historical international conference held independently by Asian and African countries, and it rallied developing countries around the great banner of unity, self-reliance, the struggle against colonialism and hegemonism as well as the promotion of world order based on peace, independence, and social justice. The Bandung spirit of "unity, friendship and cooperation" advocated by the Conference remains relevant to the contemporary international relations. China supports Indonesia to hold the relevant commemorative activities of the 6oth anniversary of the Bandung Conference, and will work closely with the Indonesian side to promote mutual understanding among Asian and African countries, deepen South-South cooperation and achieve common development (Ministry of Foreign Affairs of the People's Republic of China, 2015).
Both countries underlined the significance of Bandung Conference as a new framework towards their bilateral relationship. In that sense, Indonesia as a prominent actor of Bandung Conference has committed itself under Joko Widodo to have same vision with China over international relations matters. Naturally, behind these rhetoric agreements from Sino-India and Sino-Indonesia, there is a significant political intention that can be used by China to influence the formation of Bandung Conference Legacy. Through this arrangement, China altogether with India and Indonesia as the leaders of Bandung Conference legacy, could revise the international order by refering to the Five Principles of Peaceful Coexistence and counterattack the neoliberal value, which essentially hide the importance of individual wealth and prosperity.

Moreover, the most recent initiative was taken by China in regards to the Asian Infrastructure Investment Bank (AIIB), whose members are mostly Bandung Conference members. The establishment of such international financial institution is politically understood as an initiative to alleviate West domination at global level. Such cooperation initiative is seen as strategic attempt to win over its neighbors and other regional countries through increased trade, transport connectivity and financials support, and to establish China as Asia's 'undisputed geopolitical powerhouse' (Pan Lo, 2015). Even if this initiative was firstly put to invite only regional countries, its membership was developing significantly following the application of UK's and several European countries (Sun, 2015). On the other hand, Roul criticized that AIIB has bring different concept from West-dominated international financial institution, such as International Monetary Fund (IMF), World Bank, ADB, and others while putting heavily on social development and representing "Asia-ness" financial institution (Roul, 2015).

\section{Conclusion}

Last but not least, this paper concludes that Confucianism has been considered in $\mathrm{Xi}$ Jinping's foreign policy. As the philosophy of life in China, Confucianism was taken to 
interpret international order by putting moral and value of life as major consideration. Moreover, the interpretation of Confucianism by Xi Jinping becomes the guidance of China to resolve domestic and international affairs. Emphasizing on moral basis, $\mathrm{Xi}$ aims to revise the international order by alleviating Western values which have brought destruction and degradation of life in certain part of Third World countries. Fortunately, China's effort to renew its relationship with India as the prominent actor of Bandung Conference legacy, strengthening its relation with Indonesia, and making initiative on AIIB as revisionist international financial institution scheme have bring the possibility of "easternization" into the global order.

\section{Bibliography}

\section{Books}

Acharya, A. and Barry B. (2010) Why is There No Non-Western International Relations Theory? In: Amitav Acharya and Barry Buzan. Eds. Non-Western International Relations Theory: Perspectives On and Beyond Asia. New York: Routledge, p. 1-25.

Anwar, D. F. (2008) Indonesia and the Bandung Conference: Then and Now. In: See Seng Tan and Amitav Acharya. Eds. Bandung Revisited: The Legacy of the 1955 Asian -cAfrican Conference for the International Order. Singapore: NUS Press, p. 180197.

Bary, T. de, Wing-tsit Chan, and Chester T. (1960) Sources of Chinese Tradition, Vol. II. New York and London: Columbia University Press.

Bell, D. A. (2008) China's New Confucianism: Politics and Everyday Life in A Changing Society. Princeton: Princeton University Press.

Chan, J. (2008) Territorial Boundaries and Confucianism. In: Daniel A. Bell. Ed. Confucian Political Ethics. Princeton: Princeton University Press, p. 61-84.

Confucius. (2003) Analects: With Selections from Traditional Commentaries. Trans.: Edward Slingerland. Indianapolis: Hackett Publishing.
Cox, R. (1986) Social Forces, States and World Orders: Beyond International Relations Theory. In: Robert O. Keohane. Ed. Neorealism and Its Critics. New York: Columbia University Press, p. 204-254.

Finnane, A. (2010) Zhou Enlai in Bandung: Film as History in the People's Republic of China. In: Antonia Finnane and Derek McDougall. Eds. Bandung 1955: Little Histories. Caulfield: Monash University Press, p. 109-130.

Keith, R. C. (1989) The Diplomacy of Zhou Enlai. London: The Macmillan Press.

Kimche, D. (1973) The Afro-Asian Movement: Ideology and Foreign Policy of the Third World. Jerusalem and New York: Israel University Press.

Kotelawala, Sir J. (1956) An Asian Prime Minister's Story. George G. Harrap and co, Ltd.

Lanteigne, M. (2009) Chinese Foreign Policy: An Introduction. London and New York: Routledge.

Li, M. (2009) Soft Power: Nurture Not Nature. In: Mingjiang Li. Ed. Soft Power: China's Emerging Strategy in International Politics. New York: Lexington Books, p. 1-18.

Ming, K. (1986) Chu Hsi's Discipline of Propriety. In Wing-tsit Chan. Ed. Chu $\mathrm{Hsi}$ and Neo-Confucianism. Honolulu: University of Hawaii Press. p. 312-336.

Nehru, J. (1985) Letter Addressed to Chief Ministers, November $15^{\text {th }}$ 1954. In: G. Parthasarathi. Ed. Jawaharlal Nehru: Letters to Chief Ministers, 1947-1964. Oxford: Oxford University Press, p. 69-89.

Rainey, L D. (2010) Confucius and Confucianism: The Essentials. Oxford: Wiley-Blackwell.

Seung-hwan, L. (2006) A Topography of Confucian Discourse: Politicophilosophical Reflections on Confucian Discourse since Modernity. New Jersey: Homa and Sekey Books.

Shambaugh, D. (2013) China Goes Global: The Partial Power. Oxford: Oxford University Press. 
Wendt, A. (1992) Anarchy is What States Make of It. International Organization 46, p. 391-425.

\section{Journals}

Hess, C. A. (2010) Keeping the Past Alive: The Use of History in China's Foreign Relations. In: Shaun Breslin. Ed. Handbook of China's International Relations. New York: Routledge, p. 4754.

Liu, J. (2014) The Confucian Legacy: A Comparative Study of the Critical Inheritance of Confucianism in China and North Korea. Columbia East Asia Review 7, p. 67-94.

Paltiel, J. (2010) Mencius and World Order Theories. Chinese Journal of International Politics 3, p. 37-54.

Yang, Z. and Courtney A. V. (2014) Imagined Identity Constructs Conduits for Chinese Totalitarianism. Asian Journal of Multidisciplinary Studies 2, p. 173-183.

Yeophantong, P. (2013) Governing the World: China's Evolving Conceptions of Responsibility. Chinese Journal of International Politics 6, p. 329-364.

\section{Online Articles}

Gardels, N. (2014) Xi Launches Cultural Counter-Revolution to Restore Confucianism as China's Ideology. [Online]. The Huffington Post. Available from: <http://www.huffingtonpost.com/nat han-gardels/xi-jinpingconfucianism_b_5897680.html> [Accessed 25 March 2015].

Kai, J. (2014) The Chinese Communist Party's Confucian Revival. [Online]. The Diplomat. Available from: <http://thediplomat.com/2014/o9/t he-chinese-communist-partysconfucian-revival/> [Accessed 15 January 2015].

Krishnan, A. (2014) In China's New Diplomacy, A Revival of 'Panchsheel'. [Online]. The Hindu. Available from: <http://www.thehindu.com/todayspaper/tp-national/in-chinas-newdiplomacy-a-revival-of- panchsheel/article6146569.ece>

[Accessed 27 March 2015].

Lu, R. (2014) China's Neo-Confucianism. [Online]. Foreign Policy. Available from:

<http://foreignpolicy.com/2014/01/o 7/chinas-neo-confucianism/>

[Accessed 15 January 2015].

Ministry of Foreign Affairs of the People's Republic of China. (2015) Joint Statement on Strengthening Comprehensive Strategic Partnership between the People's Republic of China and the Republic of Indonesia. [Online]. Available from: <http://www.fmprc.gov.cn/mfa_eng/ zxxx_662805/t1249201.shtml>

[Accessed 27 March 2015].

Pan, Su-Yan, Joe Tin-Yau Lo. (2015) Reconceptualizing China's Rise as a Global Power: A Neo-tributary Perspective. [Online]. The Pacific Review. Available from: <http://dx.doi.org/10.1080/0951274 8.2015.1075578>.

Panda, A. (2014) China: Foreign Minister's India Trip Has 'Great Significance'. [Online]. The Diplomat. Available from:

<http://thediplomat.com/2014/o6/c hina-foreign-ministers-india-trip-hasgreat-significance/> [Accessed 27 March 2015].

Roul, A. (2015) Why is Asian Infrastructure Bank Different? [Online]. The Jakarta Post. Available from: <http://www.thejakartapost.com/news/2015/o7/2 3/why-asian-infrastructure-bankdifferent.html $>\quad$ [Accessed 10 December 2015].

Sun, Y. (2015) How the International Community Changed China's Asian Infrastructure Investment Bank. [Online] The Diplomat. Available from:

<http://thediplomat.com/2015/o7/h ow-the-international-communitychanged-chinas-asian-infrastructureinvestment-bank/> [Accessed 10 December 2015].

Thomas, N. (2015) Is China's Periphery Becoming the Core of Its International 
Relations? [Online] The Diplomat. Available from: <http://thediplomat.com/2015/o1/is -chinas-periphery-becoming-thecore-of-its-international-relations/> [Accessed 27 March 2015].

Tiezzi, S. (2015) China and India Want a Breakthrough on Their Border Dispute. [Online] The Diplomat. Available from: $<$ http://thediplomat.com/2015/02/c hina-and-india-want-a-breakthroughon-their-border-dispute/> [Accessed 27 March 2015].

Utami, R. (2015) Xi Jinping Hosts Jokowi in Beijing. [Online] The Jakarta Post. Available from: <http://www.thejakartapost.com/ne ws/2015/03/27/xi-jinping-hostsjokowi-beijing.html> [Accessed 27 March 2015].

Xiangwei, W. (2014) Xi Jinping Endorses the Promotion of Confucius. [Online].
South China Morning Post. Available from:

<http://www.scmp.com/news/china/ article/1603487/xi-jinping-endorsespromotion-confucius> [Accessed 25 March 2015].

Xuequan, M. (2014) China Commemorates Confucius with High-profile Ceremony. [Online]. Xinhua News. Available from: $<$ http://news.xinhuanet.com/english/ china/201409/25/c_127030072.htm> [Accessed 25 March 2015].

\section{Thesis}

Aghazarian, A. (2012) We the Peoples of Asia and Africa: The Bandung Conference and the Southernisation of the United Nations, 1955 -1970. Thesis. University of Sydney. 